\title{
Wind Frequency in Vojvodina's Part of Banat
}

Lazic, L, Pavic, D.*

Abstract The Vojvodina's part of Banat spreads through the eastern part of Vojvodina. For the analysis of wind frequencies we took the data from eight meteorological stations. We have analysed the data according to seasons and for the entire year. The winds from south-eastern ( $211 \%$ ) and north-western (148\%o) direction have the highest average frequencies. The wind from south-eastern direction - Kosava, has the highest frequency during the winter, spring and autumn, while in summer the most frequent wind is northwesterly. At the same time, most calm periods appear in summer. The highest frequency of winds is found in Northern Banat, then in the Central Banat, and the Southern Banat has the smallest wind frequency (248\%o calm period annually).

Key words wind, frequency, Banat, Vojvodina

\footnotetext{
Lazar Lazic, Dragoslav Pavic, University of Novi Sad, Faculty of Natural Sciences, Department of Geography, Tourism and Hotel Managament, Trg Dositeja Obradovića 3, 21000 Novi Sad, Serbia and Montenegro
}

\section{Position}

Yugoslav part of Banat stretches along the eastern part of Vojvodina. In the northsouth direction its position is between the Mures and the Danube rivers, and in the west-east direction between the Tisza river and the state border of Romania. The examined area occupies the area in the central part of mild climatic zone, significantly distant (about 2,000 km) from the main source of humidity, the Atlantic Ocean. At the same time, Banat is isolated from direct penetration of the cold, continental air, by the Carpathian Mountains and it penetrates only under special weather conditions. Closer to Banat is a smaller aquatic territory, the Mediterranean. However, the existence of a strong mountain barrier as the Dinaric Alps extending vertically to the direction of southern winds modifies the influence of the aquatic territory.

\section{Method}

In the research of wind frequency in Banat, data from eight meteorological stations were used, where data from seven stations are in the period 1951-1990, whereas the station Jasa Tomic gives data for the period 1954-1990. Firstly, frequency and stillness of winds will be analyzed at all stations, then in separate climatic regions and finally for the whole territory of Banat by seasons and for one year period.

List of meteorological stations and their positional characteristics, starting from the northernmost:

- Senta: 4556' North Latitude and $20^{\circ} 05^{\prime}$ East Longitude, altitude $80 \mathrm{~m}$

- Kikinda: $45^{\circ} 51^{\prime}$ North Latitude and $20^{\circ} 27^{\prime}$ East Longitude, altitude $81 \mathrm{~m}$

- Jasa Tomic: $45^{\circ} 27^{\prime}$ North Latitude and $20^{\circ} 51^{\prime}$ East Longitude, altitude $81 \mathrm{~m}$

- Zrenjanin: $45^{\circ} 24^{\prime}$ North Latitude and $20^{\circ} 25^{\prime}$ East Longitude, altitude $80 \mathrm{~m}$

- Vrsac: $45^{\circ} 09^{\prime}$ North Latitude and $21^{\circ} 19^{\prime}$ East Longitude, altitude $84 \mathrm{~m}$

- Susara: $44^{\circ} 56^{\prime}$ North Latitude and $21^{\circ} 08^{\prime}$ East Longitude, altitude $180 \mathrm{~m}$

- Bela Crkva: $44^{\circ} 54^{\prime}$ North Latitude and $21^{\circ} 25^{\prime}$ East Longitude, altitude $90 \mathrm{~m}$
- Pancevo: $44^{\circ} 53^{\prime}$ North Latitude and $20^{\circ} 40^{\prime}$ East Longitude, altitude $80 \mathrm{~m}$

Wind, together with air temperature and pressure, presents an important element of climate. Due to air movements, maritime and continental air masses exchange, i.e. air masses from different latitudes and longitudes, which differ in temperature and humidity. Thus, carrying climatic features of the area they originate, the winds strongly influence certain areas and take the role of climate modifier.

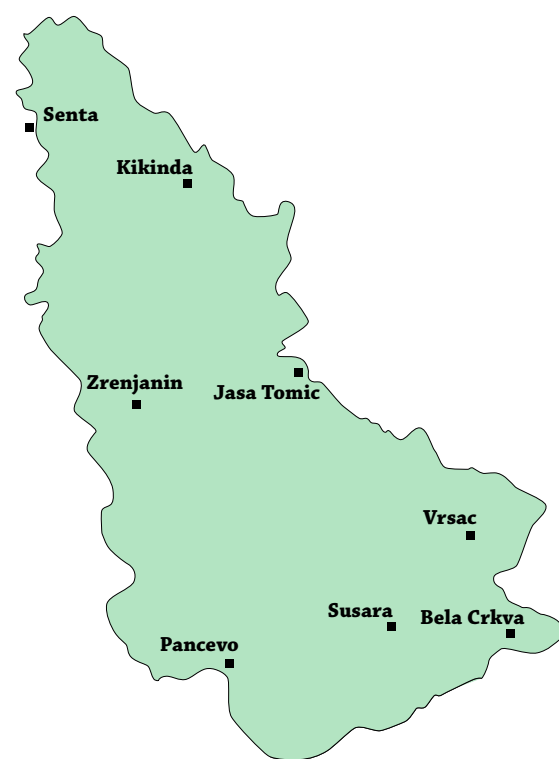

Fig 1 Positions of meteorological stations in Vojvodina's part of Banat

According to relatively small area of Banat and rather balanced air pressure, there are no significant air currents of local importance between parts of the researchcovered area. However, on the territory of Banat, and broader area of the Pannonian Basin, there are very frequent air movements caused by barometric difference between large aquatorias of The Atlantic and the Mediterranean on one hand and on the other Euro-Asian land on the other. Due to the present distribution of air activity centers on the territory of Pannonic plain, the dominating winds come from the western, or the eastern quadrant.

\section{Wind frequency}

\section{Winter}

The table 1 gives data on winter wind frequency and calmness for the observed period in eight (8) meteorological stations, by separate climatic regions and for Banat as a unit.

In Winter, the most of the territory in Banat is dominated by the southeast wind, what is the consequence of the distribution of barometric depressions in the west part 
of the Mediterranean on one hand and on the other the anticyclone above the south parts of Ukraine and Besarabia. Thus, Kosava is the wind of the highest frequency (table 1) at seven stations. Frequency of southeastern wind at these stations ranges between 185\%o (in Bela Crkva) to $318 \%$ (in Susara). In Senta, the most frequent is northwestern wind with 195\%o. It is significant that apart from southeastern and northwestern winds, there is also dominating southern wind (especially in Kikinda, Zrenjanin, and Pancevo).

The lowest frequencies in a large portion of Banat belong to the eastern wind. Its minimal frequency occurs at six stations (37\% in Vrsac and 62\%o in Zrenjanin). In Susara, the lowest frequency is recorded for northeastern and southern wind (25\%o), and in Bela Crkva for northeastern wind (26\%o).

The highest calmness during winter occurs at four southern Banat stations, where Bela Crkva (348\%) and Susara (309\%o) are singled out. Opposite to southern, northern and central parts of Banat represent rather windy areas with relatively small calmness (from 59\%o in Zrenjanin to $77 \%$ o in Senta).

All three climatic regions (table 1) are dominated during winter by the wind Kosava. The highest frequency of this wind occurs in Central Banat (255\%o), slightly lower in Southern (234\%o), and the lowest in Northern (201\%o). Apart from the southeastern wind, in all three climatic regions the frequencies of northwestern and southern wind are significant.

The lowest frequency in northern, central, and southern observed parts of Banat is recorded for eastern wind (in South Banat $43 \%$, in Central 52\%o, and in North $57 \%$ o). Low frequencies are recorded for northeastern and southwestern wind. The lowest occurrence of wind during winter is in South Banat, which is supported by the high value of calm $246 \%$. Fare more windy are North (calm is 68\%o) and Central Banat (calm is 63\%o).

Observing the whole of Banat (table 1 ), it is noticeable that the most dominating is southeastern wing with frequency of $227 \%$, and the least eastern wind with frequency values of only $48 \%$ o (graph 53).

The high frequency is recorded with winds from southwestern (135\%) and southern direction $(127 \%$ o), whereas low frequency characterizes northeastern (62\%o) and southwestern winds (67\%o). Calmness for the total Banat is $157 \%$.

\section{Spring}

During spring then distribution of dominating winds undergoes slight changes. Namely, in comparison to the winter period increased frequency of northwestern wind is observed, which is yet less frequent than southeastern wind, whereas at the same time, in most of the cases calm-
Table 1 Average winter frequencies of winds and calms (\%o) in Banat in the period 1951-1990.

\begin{tabular}{|l|r|r|r|r|r|r|r|r|r|}
\hline \multicolumn{1}{|c|}{ Winter } & \multicolumn{1}{c|}{ N } & \multicolumn{1}{c|}{ NE } & \multicolumn{1}{c|}{ E } & \multicolumn{1}{c|}{ SE } & \multicolumn{1}{l|}{ S } & SW & \multicolumn{1}{c|}{ W } & NW & \multicolumn{1}{c|}{ C } \\
\hline Senta & 118 & 78 & 58 & 177 & 107 & 80 & 110 & 195 & 77 \\
\hline Kikinda & 117 & 81 & 51 & 196 & 171 & 88 & 103 & 125 & 68 \\
\hline Jaša Tomić & 119 & 91 & 42 & 281 & 101 & 83 & 66 & 151 & 66 \\
\hline Zrenjanin & 89 & 74 & 62 & 230 & 152 & 63 & 141 & 130 & 59 \\
\hline Vršac & 88 & 63 & 37 & 222 & 207 & 74 & 75 & 77 & 157 \\
\hline Šušara & 40 & 25 & 37 & 318 & 25 & 29 & 51 & 166 & 309 \\
\hline Bela Crkva & 52 & 26 & 67 & 185 & 52 & 41 & 70 & 159 & 348 \\
\hline Pančevo & 87 & 62 & 30 & 210 & 198 & 76 & 88 & 79 & 170 \\
\hline North Banat & 108 & 78 & 57 & 201 & 143 & 77 & 118 & 150 & 68 \\
\hline Central Banat & 104 & 82 & 52 & 255 & 127 & 73 & 103 & 141 & 63 \\
\hline South Banat & 67 & 44 & 43 & 234 & 121 & 55 & 71 & 120 & 246 \\
\hline Banat & $\mathbf{8 9}$ & $\mathbf{6 2}$ & $\mathbf{4 8}$ & $\mathbf{2 2 7}$ & $\mathbf{1 2 7}$ & $\mathbf{6 7}$ & $\mathbf{8 8}$ & $\mathbf{1 3 5}$ & $\mathbf{1 5 7}$ \\
\hline
\end{tabular}

Source: Meteorological yearbooks 1951-1990.

ness becomes lower (table 2). Thus, on the observed stations still the most dominant are southeastern and northwestern winds, whereas the lowest frequency in most of the cases is recorded for the winds of eastern, southern and northeastern direction.

At seven meteorological stations, the most frequent is southeastern wind. As in winter, it is only in Senta where the highest frequency is recorded for northwestern wind. Among those seven stations, the highest frequency, $302 \%$, is recorded for southeastern wind in Susara, and the lowest, $184 \%$ o, in Kikinda. In Senta northwestern wind $(188 \%$ o) is more dominant than southeastern (165\%) for $23 \%$ o. The lowest frequency in Susara (18\%o) is recorded for southern wind, and in Bela Crkva eastern and northeastern with identical values of $29 \%$. All other stations record the lowest frequency of eastern wind. The least windy in spring are Bela Crkva and Susara, and the windiest are Kikinda, Zrenjanin and Senta. This is supported by the value of calm, which is $309 \%$ for Bela Crkva, $242 \%$ o for Susara, whereas in Kikinda its value comes to only $52 \%$ o, in Zrenjanin $55 \%$, and in Senta 57\%o.

Observing average frequencies by climatic region it is possible to understand that in all three regions the southeastern wind is

the most dominant, then follows northwestern, and then with lowest frequency eastern wind, and then winds from northeastern and southwestern directions.

The highest frequency is recorded for southeastern wind in Central Banat $(249 \%$ o), then in South Banat (234\%o), and the lowest in North (189\%o). Northwestern wind, observed regionally, shows noticeable standardized frequency. Namely, it is the most frequent in southern (172\%o), slightly lower in northern (162\%o), and the lowest in central (159\%) part of the observed area. It is also important to emphasize that the north wind is frequent too, especially in the north and central parts of Banat.

Eastern wind, which is of far lowest frequency, reaches its minimum in South Banat (41\%o), slightly higher in Central (48\%) and the highest in North (57\%o). As it has been quoted here, relatively low frequencies characterize northeastern and southwestern winds.

The most windy parts are the north parts of Banat where the value of calm is only $55 \%$, central parts follow immediately with calm $65 \%$, whereas the least windy parts are those in the south of the observed area where the frequency is the highest (199\%o).

Table 2 Average spring frequencies of winds and calms (\%o) in Banat in the period 1951-1990.

\begin{tabular}{|l|r|r|r|r|r|r|r|r|r|}
\hline \multicolumn{1}{|c|}{ Spring } & \multicolumn{1}{c|}{ N } & \multicolumn{1}{c|}{ E } & \multicolumn{1}{l|}{ SE } & \multicolumn{1}{c|}{ S } & SW & W & NW & \multicolumn{1}{c|}{ C } \\
\hline Senta & 145 & 84 & 57 & 165 & 113 & 90 & 101 & 188 & 57 \\
\hline Kikinda & 138 & 93 & 55 & 184 & 124 & 96 & 98 & 160 & 52 \\
\hline Jaša Tomić & 121 & 86 & 38 & 282 & 73 & 88 & 57 & 180 & 75 \\
\hline Zrenjanin & 123 & 72 & 58 & 217 & 134 & 73 & 130 & 138 & 55 \\
\hline Vršac & 101 & 90 & 39 & 221 & 159 & 72 & 83 & 101 & 134 \\
\hline Šušara & 40 & 30 & 45 & 302 & 18 & 30 & 69 & 224 & 242 \\
\hline Bela Crkva & 61 & 29 & 29 & 192 & 61 & 58 & 87 & 174 & 309 \\
\hline Pančevo & 103 & 79 & 49 & 223 & 90 & 57 & 99 & 190 & 110 \\
\hline North Banat & 135 & 83 & 57 & 189 & 124 & 86 & 110 & 162 & 55 \\
\hline Central Banat & 122 & 79 & 48 & 249 & 103 & 81 & 94 & 159 & 65 \\
\hline South Banat & 76 & 57 & 41 & 234 & 82 & 54 & 85 & 172 & 199 \\
\hline Banat & $\mathbf{1 0 4}$ & $\mathbf{7 0}$ & $\mathbf{4 6}$ & $\mathbf{2 2 3}$ & $\mathbf{9 7}$ & $\mathbf{7 1}$ & $\mathbf{9 1}$ & $\mathbf{1 6 9}$ & $\mathbf{1 2 9}$ \\
\hline
\end{tabular}

Source: Meteorological yearbooks 1951-1990. 
Table 3 Mean summer wind frequency and calm (\%o) in Banat for the period 1951-1990.

\begin{tabular}{|l|r|r|r|r|r|r|r|r|r|}
\hline \multicolumn{1}{|c|}{ Summer } & \multicolumn{1}{c|}{ N } & \multicolumn{1}{c|}{ NE } & \multicolumn{1}{c|}{ E } & \multicolumn{1}{c|}{ SE } & \multicolumn{1}{c|}{ S } & SW & \multicolumn{1}{c|}{ W } & NW & \multicolumn{1}{c|}{ C } \\
\hline Senta & 129 & 89 & 53 & 133 & 100 & 85 & 121 & 192 & 98 \\
\hline Kikinda & 130 & 97 & 58 & 145 & 92 & 79 & 117 & 187 & 95 \\
\hline Jaša Tomić & 127 & 81 & 48 & 179 & 65 & 85 & 65 & 225 & 125 \\
\hline Zrenjanin & 127 & 80 & 58 & 141 & 104 & 73 & 163 & 174 & 80 \\
\hline Vršac & 116 & 80 & 43 & 138 & 134 & 80 & 94 & 123 & 192 \\
\hline Šušara & 83 & 54 & 39 & 129 & 79 & 79 & 114 & 123 & 300 \\
\hline Bela Crkva & 51 & 29 & 36 & 103 & 40 & 54 & 123 & 160 & 404 \\
\hline Pančevo & 97 & 73 & 48 & 151 & 122 & 91 & 100 & 118 & 200 \\
\hline North Banat & 129 & 89 & 56 & 140 & 99 & 79 & 134 & 184 & 91 \\
\hline Central Banat & 127 & 80 & 53 & 160 & 84 & 79 & 114 & 200 & 103 \\
\hline South Banat & 87 & 59 & 41 & 130 & 94 & 76 & 108 & 131 & 274 \\
\hline Banat & $\mathbf{1 0 7}$ & $\mathbf{7 3}$ & $\mathbf{4 8}$ & $\mathbf{1 4 0}$ & $\mathbf{9 2}$ & $\mathbf{7 8}$ & $\mathbf{1 1 2}$ & $\mathbf{1 6 3}$ & $\mathbf{1 8 7}$ \\
\hline
\end{tabular}

Source: Meteorological yearbooks 1951-1990.

On the area of the whole Banat (table 2) the most dominant are southeastern (223\%o), and northwestern winds (169\%o), and the least frequent winds from the eastern (46\%o), northeastern (70\%o), and southwestern $(71 \%$ o) directions. The number of calmness is significant - $129 \%$ o.

\section{Summer}

Highly noticeable changes in wind frequency distribution are recorded during summer in comparison to winter and spring period, what primarily refers to significant increase in northwestern and decrease in southeastern wind occurrence. According to Katic et all (1979), this is the consequence of high air pressure values above the Atlantic Ocean and low air pressure values above Central Asia, as well as of frequent passes of barometric depressions above the Adriatic and Mediterranean.

Thus, at five measure stations (Senta, Kikinda, Jasa Tomic, Zrenjanin, and Bela Crkva) the highest occurrence is recorded for northwestern wind, whereas at other three measure stations (Vrsac, Susara, and Pancevo) it is recorded for southeastern wind well known as Kosava (table 3). Northwestern wind frequency values at five-mentioned measure stations range from 160\%o (Bela Crkva) to 225\%o (Jasa Tomic), whereas southeastern wind frequency values range from 151\%o (Pancevo), $138 \%$ o (Vrsac) to $129 \%$ o (Susara). It is important to emphasize that apart from those winds rather frequent distribution is recorded for winds of north and west directions.

The lowest frequency rate, which is the same as in two earlier seasons, are recorded even at seven measure stations for eastern wind (ranging from 39\%o Susara, to $58 \%$ o Kikinda and Zrenjanin). It is only in Bela Crkva where the lowest occurrence rate is recorded for northeastern wind (29\%o) which is $7 \%$ o less than recorded for the eastern wind. During summer, other winds of relatively low frequency are recorded at measure stations, e.g. south- western wind (Senta, Kikinda, Zrenjanin) and western (Jasa Tomic).

The significant feature of summer period is increase in calmness, which, during this warmest season in Banat, ranges from $80 \%$ o (Zrenjanin) to remarkably $404 \%$ o (Bela Crkva).

There are no significant deviations by climatic regions (table 3 ). The most dominant winds in all three regions are northwestern, then follow southeastern, whereas the lowest frequency in all three regions is recorded for eastern wind, and then for winds from southwestern and northeastern directions.

The highest frequency of $200 \%$ o is recorded for the northwestern wind in Central Banat, whereas in North Banat frequency of this wind is $184 \%$, and in South Banat $131 \%$. Southeastern wind, which lags behind the northwestern in frequency value, has the same frequency distribution by climatic regions. Namely, its frequency in Central Banat is $160 \%$ o, in North Banat $140 \%$, and in South $130 \%$. Also, north and west winds have significant frequency distribution in North and Central Banat.

East wind, which is the most rare during this season, records the lowest frequency in South Banat (41\%), slightly higher in Central (53\%o) and North Banat (56\%o).

During summer, South Banat with calm of $274 \%$ o represents the part of the
Source: Meteorological yearbooks 1951-1990. researched area with lowest wind frequency. Windier are Central (calm 103\%o) and northern parts of Banat (calm 91\%o).

On the whole region of Banat (table 3 ), the most prevailing winds are northwestern $(163 \%$ ) and southeastern (140\%o) winds, whereas the lowest frequency is recorded for eastern wind (48\%o). Low distribution is recorded for northeastern (73\%o) and southwestern $(78 \%$ ) winds.

\section{Autumn}

During autumn, the distribution of anticyclone and cyclone in broader district is such that again on the territory of Banat the most frequent is southeastern wind, far more than during winter and spring (table 4). All eight measure stations record the dominance of southeastern wind. Its frequency ranges from $206 \%$ (Senta) to $333 \%$ (Susara). The second place in frequency is shared between northwestern (Senta, Jasa Tomic, Susara, Bela Crkva, and Pancevo) and southern (Kikinda, Zrenjanin, and Vrsac) winds. According to earlier researches (Katic et all. 1979) southern wind in Banat in winter shows higher frequency distribution in comparison to other seasons.

Eastern wind is the least frequent in autumn in most of Banat. Namely, in Senta (62\%o), Vrsac (44\%o), and Pancevo (332\%o) the lowest frequencies were recorded, whereas at measure station Jasa Tomic together with western wind (53\%o), and in Zrenjanin (66\%o) together with southwestern wind it records the lowest frequency. In Kikinda (64\%o) and Bela Crkva (22\%o), the lowest frequency was recorded for northeastern, and in Susara $(22 \% \circ 0$ southern wind. It is also important to say that at measure stations of South Banat, apart form southeastern, in Susara apart from northwestern, and in Pancevo apart from southern winds, the winds from other directions recorded extremely low frequencies. Here calms are rather frequent and range from $160 \%$ in Vrsac to $421 \%$ in Bela Crkva. Calms in the northern and Central parts of Banat are of significantly lower frequency, which rang-

Table 4 Mean autumn wind frequency and calm (\%o) in Banat for the period 1951-1990.

\begin{tabular}{|l|r|r|r|r|r|r|r|r|r|}
\hline \multicolumn{1}{|c|}{ Autumn } & N & NE & \multicolumn{1}{|c|}{ E } & SE & \multicolumn{1}{l}{ S } & SW & \multicolumn{1}{c|}{ W } & NW & \multicolumn{1}{c|}{ C } \\
\hline Senta & 109 & 74 & 62 & 206 & 123 & 81 & 101 & 178 & 66 \\
\hline Kikinda & 116 & 64 & 66 & 231 & 144 & 85 & 94 & 130 & 70 \\
\hline Jaša Tomić & 100 & 94 & 53 & 295 & 79 & 81 & 53 & 155 & 90 \\
\hline Zrenjanin & 92 & 70 & 66 & 245 & 147 & 66 & 128 & 121 & 65 \\
\hline Vršac & 88 & 73 & 44 & 244 & 172 & 62 & 73 & 84 & 160 \\
\hline Ššara & 33 & 29 & 55 & 333 & 22 & 26 & 44 & 139 & 319 \\
\hline Bela Crkva & 33 & 22 & 59 & 208 & 48 & 44 & 77 & 88 & 421 \\
\hline Pančevo & 51 & 63 & 32 & 270 & 190 & 60 & 53 & 91 & 190 \\
\hline North Banat & 106 & 69 & 65 & 227 & 138 & 77 & 108 & 143 & 67 \\
\hline Central Banat & 96 & 82 & 59 & 270 & 113 & 73 & 91 & 138 & 78 \\
\hline South Banat & 51 & 47 & 47 & 264 & 108 & 48 & 62 & 100 & 273 \\
\hline Banat & $\mathbf{7 8}$ & $\mathbf{6 1}$ & $\mathbf{5 5}$ & $\mathbf{2 5 4}$ & $\mathbf{1 1 6}$ & $\mathbf{6 3}$ & $\mathbf{7 8}$ & $\mathbf{1 2 3}$ & $\mathbf{1 7 2}$ \\
\hline
\end{tabular}


es from $65 \%$ (Zrenjanin) to $90 \%$ (Jasa Tomic).

In all three climatic regions (table 4) the most dominant is southeastern wind, whereas winds from eastern and northeastern direction blow quite rarely. Southeastern wind records the highest frequency in Central Banat (270\%o), in Southern Banat $6 \%$, less which is (264\%o), and the least in the northern part of the area covered by the research (227\%o). By the frequency of occurrence right behind southeastern wind in North and Central Banat, there is the wind from northwestern, and in South Banat the wind from southern direction.

The lowest frequency rate of $47 \%$ o is recorded for eastern wind, together with western in the southern part of Banat, whereas in the central area (59\%o) and in the northern parts $(65 \%)$ of the researched area eastern wind occupies the last place by frequency. It is easily observed that in South Banat, winds from south and northwest are of low distribudirections other than southeast, partly

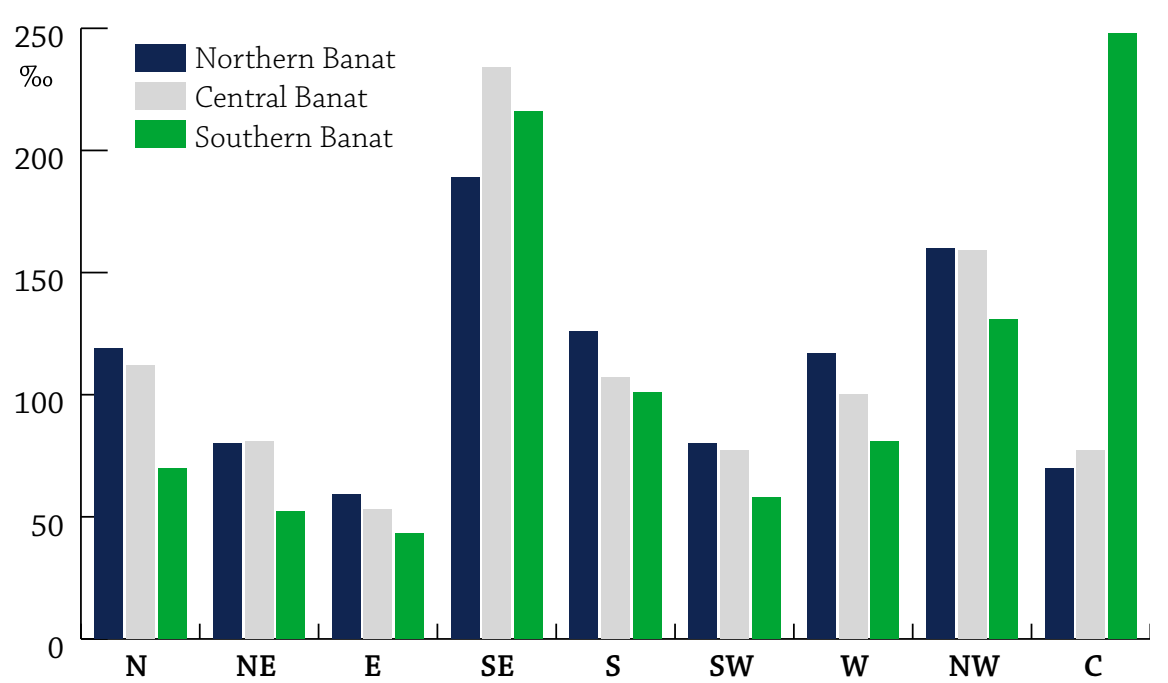

Fig 2 Average annual winds and calm periods (\%o) for the Northern, Central and Southern Banat in the period 1951-1990.

According to data in table 5 , on the whole area covered, the most dominant are winds from southeastern and northwestern direction, whereas the least frequent are winds from eastern and northeast-

Table 5 Mean annual wind frequency and calm (\%o) in Banat for the period 1951-1990.

\begin{tabular}{|l|r|r|r|r|r|r|r|r|r|}
\hline \multicolumn{1}{|c|}{ Annual } & \multicolumn{1}{c|}{ N } & \multicolumn{1}{c|}{ NE } & \multicolumn{1}{c|}{ E } & \multicolumn{1}{c|}{ SE } & \multicolumn{1}{c|}{ S } & SW & \multicolumn{1}{c|}{ W } & NW & \multicolumn{1}{c|}{ C } \\
\hline Senta & 125 & 81 & 58 & 170 & 111 & 84 & 108 & 188 & 75 \\
\hline Kikinda & 125 & 84 & 58 & 189 & 133 & 87 & 103 & 150 & 71 \\
\hline Jaša Tomić & 117 & 88 & 45 & 259 & 80 & 84 & 60 & 178 & 89 \\
\hline Zrenjanin & 108 & 74 & 61 & 208 & 134 & 69 & 140 & 141 & 65 \\
\hline Vršac & 98 & 77 & 41 & 206 & 168 & 72 & 81 & 96 & 161 \\
\hline Šušara & 49 & 34 & 44 & 270 & 36 & 41 & 70 & 163 & 293 \\
\hline Bela Crkva & 49 & 27 & 48 & 172 & 50 & 49 & 89 & 145 & 371 \\
\hline Pančevo & 84 & 69 & 40 & 214 & 150 & 71 & 85 & 119 & 168 \\
\hline North Banat & 119 & 80 & 59 & 189 & 126 & 80 & 117 & 160 & 70 \\
\hline Central Banat & 112 & 81 & 53 & 234 & 107 & 77 & 100 & 159 & 77 \\
\hline South Banat & 70 & 52 & 43 & 216 & 101 & 58 & 81 & 131 & 248 \\
\hline Banat & $\mathbf{9 4}$ & $\mathbf{6 7}$ & $\mathbf{4 9}$ & $\mathbf{2 1 1}$ & $\mathbf{1 0 8}$ & $\mathbf{7 0}$ & $\mathbf{9 2}$ & $\mathbf{1 4 8}$ & $\mathbf{1 6 1}$ \\
\hline
\end{tabular}

Source: Meteorological yearbooks 1951-1990.

tion. As it has already been said, calms are the most frequent here (273\%o), whereas in the central (78\%o) and in northern $(67 \%$ ) parts of the researched area they are of lower frequency. On the whole territory of Banat (table 4), according to expectations, the most dominant is the southeastern wind $(254 \%$ o), then follow winds from northwestern direction (123\%o), and southern (116\%o) direction. Conversely, the lowest frequency shows eastern (55\%o), northeastern (61\%o), and southwestern (63\%o) winds (graph 59). The average calm for the whole Banat is $172 \%$.

\section{Annual}

Mean annual wind frequency and calm in Banat represent the result of the existing view of frequency and clam by seasons. On the basis of annual mean values it is difficult to define the correlation between frequency of winds from different directions, as well as frequency of calm by seasons, which undoubtedly exist. ern direction. At seven measure stations, the most frequent during a year is southeastern wind (from 172\% in Bela Crkva to $270 \%$ in Susara), whereas in Senta the most dominant is northwestern wind with

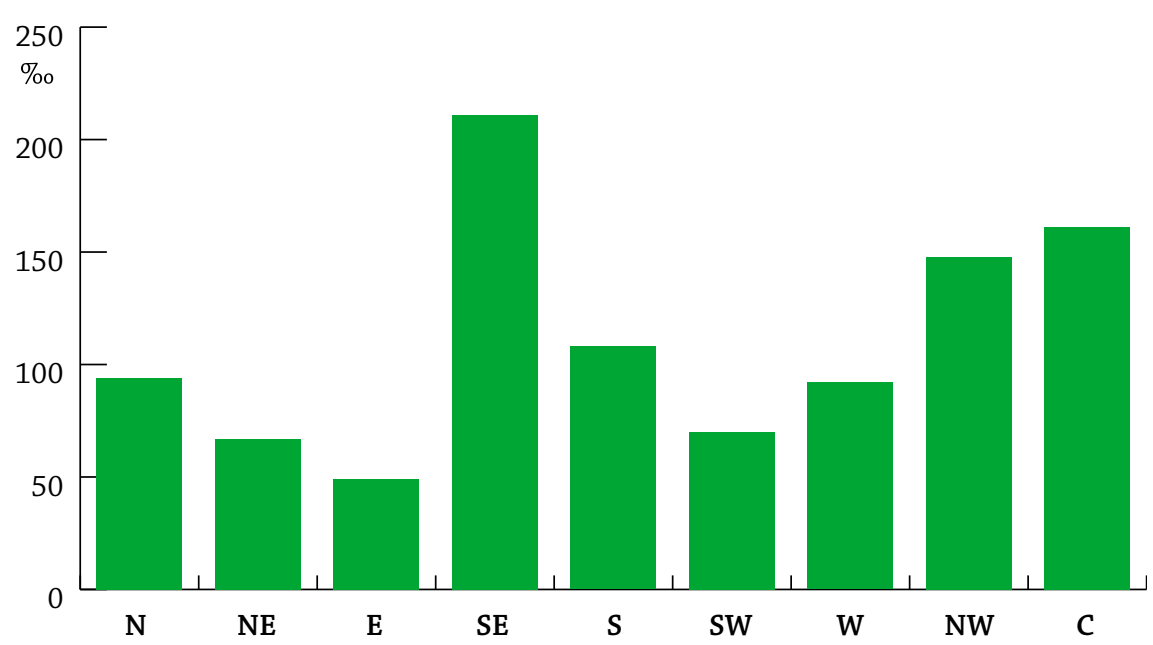

Fig 3 Average annual winds and calm periods (\%o) for Banat in the period 1951-1990. frequency of $188 \%$ o (southeastern wind in Senta is less frequent than northwestern wind for $18 \%$ o). It is important to emphasize that in Vrsac (168\%o) and in Pancevo (150\%o), the occurrence of southern wind is rather frequent.

At six measure stations the least frequent are the winds from eastern direction (40\%o in Pancevo and $61 \%$ o in Zrenjanin), and northeastern direction (34\%o Susara and 27\%o Bela Crkva). Besides the aforementioned, relatively low frequency is recorded for southwestern (Zrenjanin, Vrsac), southern (Susara) and western (Jasa Tomic) winds.

The highest frequency of mean annual calm is recorded at measure stations in the south of Banat (from 161\%o in Vrsac to $371 \%$ o in Bela Crkva), whereas calm at stations in North and Central Banat far less frequent and its occurrence ranges from $65 \mathrm{v}$ (Zrenjanin) to $89 \%$ (Jasa Tomic).

The highest mean annual frequencies in all three climatic regions (table 5) belong to southeastern and northwestern winds. The lowest mean annual frequencies belong to eastern, southwestern and northeastern winds. 
Southeastern wind shows the highest frequency in Central Banat (234\%o), slightly lower in South (216\%), and the lowest in North (189\%o). Annual frequencies of northwestern wind gradually decrease from southwards (from 160\%o to $131 \%$ o). Significant frequency of occurrence in North and Central Banat is recorded for winds from north and west direction.

Eastern wind shows the lowest frequency in all three regions and its values decreases southwards (from 59\%o to $43 \%$ o). Low frequency, especially in South Banat, is recorded for northeastern (52\%o) and southwestern (58\%o) winds. The highest annual calm is recorded for southern parts of Banat (248\%), whereas in Central (77\%o) and in North Banat (70\%o) the value of calm is lower.
On the whole area of Banat the highest mean annual frequency (table 5) is recorded for winds from southeastern (211\%o) and northwestern (148\%o) directions, and the lowest mean annual frequency is recorded for winds from eastern (49\%o), northeastern (67\%o) and southwestern $(70 \%$ o) direction. The value of mean annual calm is $161 \%$.

\section{Conclusion}

Analyzing the data, it is possible to say that during the year on the whole territory of Vojvodinian part of Banat, the winds of highest frequency are those from southeastern $(211 \%$ ) and northwestern (148\%o) quadrant. The wind from the southeastern quadrant - Kosava has the highest frequency value during winter, spring, and autumn, whereas in summer the most frequent wind is that from northwestern quadrant. At the same time, the highest calm occurs during the summer period.

The highest wind frequency was recorded for North Banat, then for Central Banat, and the lowest values were recorded for South Banat (248\%o annually).

\section{References}

Dukic, D. (1981), Klimatologija, Naucna knjiga, Beograd.

Katic,P., Djukanovic, D., Djakovic., (1979), Klima SAP Vojvodine, Poljoprivredni fakultet, Novi Sad.

Meteoroloski godisnjaci (1951-1990), Savezni hidrometeoroloski zavod, Novi Sad.

Milosavljevic, M. (1951), Klimatografska skica NR Srbije, Institut za vodoprivredu, Beograd.

Vujevic, P. (1948), Meteorologija, Prosveta, Beograd. 